\title{
PEMBENTUKAN IDENTITAS SOSIAL PEREMPUAN PADA ZAMAN ORDE BARU DALAM NOVEL SAMAN KARYA AYU UTAMI
}

\author{
Zalifa Nuri \\ Universitas Padjadjaran, zalifa18001@,mail.unpad.ac.id \\ Susi Machdalena \\ Universitas Padjadjaran, machdalena@,unpad.ac.id
}

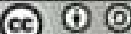

(C)2020 by the authors. Submitted for possible open access publication under the terms and conditions of the Creative Commons Attribution-ShareAlike 4.0 International License (CC-BY-SA) license (https://creativecommons.org/licenses/by-sa/4.0/) d DOI : http://dx.doi.ong/10.30983/ bumanisme.v4i2

\begin{abstract}
This paper discusses the formation of women's identity in the novel Saman. Lately, women's social identity has changed in meaning with the times, so the author wants to analyze the identity of women in this novel. This novel has a background in the New Order era, the author wants to analyze how the formation of women's identity at that time. This paperis a qualitative approach with descriptive study by the writer reading the novel. The author uses Henri Tajfel's Theory of identity which explains that social identity is part of the concept of each individual who comes from his membership and is in a social group where the social group has the same values and emotional significance in the membership. The results of the analysis show that there is a strong influence from the socialization stage of parents to children because parents are the first and foremost people who carry out social interactions with children. In addition, in the novel, during the New Order era, there was a state policy towards women or mothers/parents with the five dharma program so that it had an influence on the formation of women's identity, besides that the influence of the environment and policies in the New Order era had a strong influence on the formation of women's identity.
\end{abstract}

Keywords: Social identity, Ideology, Women, New order.

\begin{abstract}
Abstrak
Tulisan ini membahas tentang pembentukan identitas perempuan dalam novel Saman. Akhir akhir ini identitas sosial perempuan menjadi berubah arti seiring berkembangnya zaman, oleh sebab itu penulis ingin menganalisis tentang identitas perempuan pada novel ini. Novel ini berlatar belakang waktu pada zaman orde baru, penulis ingin menganalisis bagaimana pembentukan identitas perempuan pada zaman itu. Tulisan ini merupakan penelitian kualitatif dengan studi deskriptif dengan cara penulis membaca novel tersebut. Penulis menggunakan Teori identitas Henri Tajfel menjelaskan terkait identitas sosial yaitu sebagai sebuah konsep pada setiap individu yang asal muasalnya dari keanggotaan komunitas dan berada dalam komunitas sosial tersebut, komunitas tersebut merupakan kelompok sosial yang memiliki kesamaan nilai serta kesamaan emosional dalam keanggotaan komunitas tersebut. Hasil analisis menunjukkan adanya pengaruh kuat dari tahap sosialisasi orang tua pada anak dikarenakan orang tua adalah orang pertama dan utama yang melakukan interaksi sosial dengan anak. Selain itu, dalam novel itu di masa orde baru ada kebijakan negara terhadap para perempuan atau ibu/orang tua dengan programnya panca dharma sehingga memberikan pengaruh pada pembentukan identitas perempuan, selain itu pengaruh lingkungan dan kebijakan pada zaman orde baru memberi pengaruh kuat dalam pembentukan identitas perempuan.
\end{abstract}

Kata kunci : Identitas sosial, Ideologi, Perempuan, Orde baru 


\section{Latar Belakang}

Kehidupan sosial di alam ini dapat diekspresikan dengan berbagai wacana fiktif maupun non fiktif, salah satu yang bisa mengekspresikan adalah karya sastra. Karya sastra merupakan karya yang merepresentasikan kejadian nyata atau faktual yang terjadi dalam kehidupan. Pengarang karya sastra menceritakannya kembali dengan tambahan usnur-unsur imajinatif dan kreatif dari pengarang. ${ }^{1} \quad$ Terdapat beberapa pengertian karya sastra, diantaranya karya sastra merupakan salah satu alat untuk memperkenalkan budaya sebuah bangsa karena di dalamnya tertulis tentang budaya bangsa tersebut baik secara tersirat maupun tersurat. $^{2}$ Karya sastra adalah merupakan karya fiksi, hal yang berlawanan dari karya fiksi adalah karya non fiksi, seperti opini, esai, biografi, dan sebagainya.

Terdapat salah satu tulisan dalam Humanisma $^{3}$ yang mengekspresikan nasib perempuan Minangkabau dalam pandangan karya-karya fiksi pada saat terjadinya pemberontakan di daerah. Berdasarkan hasil penelitian itu, nasib perempuan dalam karyakarya fiksi tersebut memiliki satu pola, bahwa perempuan adalah korban dari perang lakilaki, baik sebagai korban perkosaan, korban pelecehan, korban 'penipuan' sebagai ganjal batu maupun kayu.

Dalam karya sastra terdapat cara pandang sastrawan pada lingkungan pada

${ }^{1}$ Diki Febrianto, Purwati Anggraini, Representasi Pewayangan Modern: Kajian Antropologi Sastra dalam Novel Rabvayana Aku Lala Padamu karya Sujiwo Tejo, Jentera: Jurnal Kajian Sastra, Vol.8, No.1, Juni 2019, h.13

${ }^{2}$ Sarastika E. Hapriyonita, Teknik Dan Metode Penerjemahan Novel Naib 'Trail Oleb Kamran As'ad Irsyady (Kajian Terjemah), Skripsi, 2018.

${ }^{3}$ Dedi Arsa, Sjarikat Simpan-Pinjamdan Kongsi Oesaba: Respon Atas Moneterisasi Kolonial, HUMANISMA: Journal of Gender Vol. 1 , No. 2, 2017, h. 116 waktu tertentu, selain pandangan terhadap lingkungan, terdapat pula pandangan pada gender. Salah satunya perempuan, banyak karya sastra yang memberi pandangan terhadap perempuan. Contohnya novel Perempuan di Titik Nol karya Nawal elSaadawi, cerpen Sagra karya Oka Rusmini. Salah satu karya sastra yang terkenal adalah novel. Menurut Wiendy dikutip dari Sumardjo, dkk sebabnya karena novel mempunyai kapasitas komunikasi yang luas, sehingga dapat dengan mudah dinikmati masyarakat. ${ }^{4}$

Dalam novel tentunya terdapat beberapa karakter yang diceritakan di dalamnya, salah satunya Perempuan. Perempuan disebut manusia berjenis kelamin betina. Menurut Akmaliyah mengutip dari situs steady health dalam aspek gender perempuan diartikan mempunyai sifat yang kental pada seorang individu untuk menjadi dan bersifat keperempuanan. Adapun pengertian perempuan secara fisik adalah menunjukkan sebagai salah satu jenis kelamin yang memiliki ciri alat dan fungsi reproduksi yaitu berupa payudara, sel telur untuk melahirkan serta wadah rahim tempat tumbuh kembangnya janin. Sehingga dengan ciri tersebut perempuan dapat hamil, melahirkan dan menyusui anaknya. Sedangkan laki-laki berbeda dari segi fisik, yaitu lebih tinggi dari perempuan dan lebih kuat $30 \%$ dari perempuan. ${ }^{5}$

Menurut Akmaliyah, dikarenakan adanya perbedaan psikologis ini, seringkali budaya masyarakat memperlakuan laki-laki

${ }^{4}$ Wiendi Wiranty, Tindak Tutur dalam Wacana NovelLaskar Pelangi Karya Andrea Hirata(Sebuah Tinjauan Pragmatik), Jurnal Pendidikan Bahasa, Vol. 4, No. 2,2015, h. 295

${ }^{5}$ Akmaliyah, Pendidikan Kesetaraan Gender Perspektif Islam, Skripsi, 2009. 
dan perempuan tidak sama. ${ }^{6}$ Setiap adanya perubahan zaman, kondisi perempuan mengalami perubahan pula. Misalnya saja perempuan pada masa pra Islam, perempuan pada zaman itu dianggap sebagai obyek yang diwariskan. ${ }^{7}$ Kemudian Islam datang menyelamatkan perempuan dengan ajaran yang dibawa Muhammad S.A.W, hingga saat ini, perempuan diberi kesempatan berkarya dan dihargai. Meskipun pada kenyataannya belum sepenuhnya dihargai. Contohnya dikutip dari catatan tahunan kekerasan perempuan Komnas Perempuan tahun 2018, terdapat 5.114 kasus kekerasan terhadap istri atau dalam persentasi sebesar 53\%. Kekerasannya berupa perkosaan dalam perkawinan. $^{8}$

Melihat kenyataan tersebut ada begitu banyak tantangan yang harus dilalui dan diperjuangkan oleh perempuan. Bentuk perjuangan dapat dilakukan dengan berbagai cara, diantaranya melalui karya sastra atau novel. Hasil karya sastra atau novel tersebut dapat ditanggapi atau dikritisi nilai feminismenya atau perjuangannya (kritik sastra feminis) terhadap perempuan.

Pada novel ini, ditemukan pembentukan identitas sosial yang terjadi di masa orde baru khususnya yang dituangkan dalam novel Saman. Kriteria orde baru digambarkan dengan masa pemerintahan pada tahun 1998 yang diungkapkan dalam novel ini. Hal ini ditunjukan dari seorang tokoh bernama Saman yang merupakan aktivis yang memiliki jiwa sosial, sedang

\footnotetext{
${ }^{6}$ Akmaliyah, Al-Kalimat Al-Muta'lliqah bi AlMusawah Al-jenderiyah fi Al-Lugah Al-Arabiyyah wa AlIndonesiyyah, Musâwa, Vol. 15 No. 2 Juli 2016.

${ }^{7}$ Zunly Nadia, Peran dan Aktivitas Perempuan Era Mubammad SAW (Studi Atas Hadis-Hadis Riwayat Sahabat Perempuan), Humanisma: Journal of Gender Studies, Vol.04, No.01, 2020, h. 17

${ }^{8}$ Catatan Kekerasan Terbadap Perempuan Tabun 2018, Komnas Perempuan, Rabu 6 Maret 2019.
}

melakukan proyek lalu tiba-tiba terjadi penyergapan sehingga Saman dimasukan ke penjara. Di dalamnya Saman disiksa, dituduh sebagai anggota komunis.

Tapi bagaimanapun yang kemudian ia terima membikin tubuhnya gemetar. Kegentaran itu tetap muncul setiap kali ia di giring ke ruang interrogáis, didudukan atau dibarkan berdiri, sementara ia menduga-duga cara apa yang digunakan orang-orang kali ini, sebab matanza selalu ditutup. Kadang mereka menyundut dengan bara rokok, menjepit jari-jarinya, mencambuknya meski tidak di dada, menyetrum lehernya, atau Cuma menggunakan kepalan dan tendangan.'

Pada masa orde baru mengemukan dan dikenal dengan demonstrasi Mei 1998 sementara kajian ini ingin menyampaikan pesan sebuah ekspresi dari karya yang terbit pada tahun yang sama tentang pembentukan identitas sosial perempuan yang digambarkan dalam novel ini. Ada kegelisahan yang ingin disampaikan bahwa masih perlu dikaji tentang pembentukan identitas sosial dari masa ke masa termasuk kajian ini pada masa orde baru.

Salah satu novelis yang dalam karyanya mengekspresikan perempuan yaitu Ayu Utami. Ayu Utami bernama lengkap Justina Ayu Utami. Dia lahir di kota Bogor, Jawa Barat, pada 21 November 1968. Dia merupakan seorang jurnalis sekaligus sastrawati berkebangsaan Indonesia. Dia berkembang dan tumbuh besar di Jakarta dan menyelesaikan pendidikannya di Fakultas Sastra Universitas Indonesia.

Ayu terkenal sebagai novelis sejak novelnya Saman mendapat penghargaan dan memenangkan sayembara penulisan roman Dewan Kesenian Jakarta 1998. Kemudian dalam waktu kurun tiga tahun novel Saman telah terjual sebanyak 55 ribu eksemplar. Berkat karya novel Saman itu pula, akhirnya

${ }^{9}$ Ayu Utami, (1998), Saman, Jakarta: Kepustakaan Populer Gramedia, h. 106 
Ayu Utami memeproleh penghargaan Prince Claus Award 2000 dari Prince Claus Fund, sebuah yayasan yang kantor pusatnya terletak di Den Haag, Belanda. Di penghujung tahun 2001, ia juga menerbitkan karya novel Larung. Beberapa karyanya yaitu novel Saman, Larung, Bilangan Fu, Manjali Dan Cakrabirawa, Cerita Cinta Enrico, Soegija: 100\% Indonesia, Lalita (Seri Bilangan Fu), Si Parasit Lajang, Pengakuan: Eks Parasit Lajang, dan novel Maya. ${ }^{10}$

Salah satu novel karya Ayu Utami akan menjadi topik kajian dalam tulisan ini yaitu novel dengan judul Saman. Novel ini mengekspresikan tentang perempuan pada zaman orde baru. Maka, menarik untuk dikaji apa yang digambarkan penulis dalam novel tersebut tentang perempuan, khususnya mengupas tentang identitas gender pada masa itu.

\section{Metode}

Penulis menggunakan metode analisis isi dengan teknik deskriptif. Menurut Eriyanto yang dikutip oleh Teta, dkk (2018) analisis isi adalah analisis yang menggunakan sebuah dokumentasi atau teks lalu mengamatinya secara objektif. Di mana penulis menganalisis novel ini mengacu pada teks di novel. Setelahnya penulis mendeskripsikan apa yang didapat dari teks itu dan menganalisis sesuai dengan aspek yang dipilih oleh penulis.

Metodologi kualitatif menurut Bodgan dan Taylor seperti dikutip Rahmi adalah langkah penelitian yang berasal dari perbuatan yang diamati. Penelitian ini akan

\footnotetext{
${ }^{10}$ Ayu Utami. (2020). Wikipedia. Diakses pada 3 Agustus 2020, darihttps://id.wikipedia.org/wiki/Ayu_Utami.
}

menghasilkan data deksriptif berupa pernyataan tertulis. ${ }^{11}$

Dalam pembentukan identitas seseorang atau ciri khas seseorang berbedabeda, dalam kemunculan atau pembentukan identitas tersebut, terdapat proses - proses yang dihadapi. Menurut Erickson yang dikutip dari artikel Uswatun (2013) ${ }^{12}$ elemen yang dapat berpengaruh dalam pembentukan identitas adalah lingkungan, komunitas acuan dan individu yang disukai atau role model.

Kebudayaan juga dapat berpengaruh dalam mengidentifikasi diri, seperti yang dikatakan oleh Atwater (1999) dalam artikel Uswatun $^{13}$ bahwa cara mensosialisasikan budaya ini akan berpengaruh pada identitas seseorang. Pada novel ini penulis menggunakan teori identitas yang dijadikan dasar teori utama pada penelitian ini yaitu Teori Identitas Sosial Henri Tajfel. Penulis menggunakan teori ini karena disebutkan bahwa teori menitik beratkan bahwa identitas berasal dari dalam sebuah kelompok sosial yang berdampak persepsi relevan dengan keanggotaan. Penulis bermaksud mencari tahu identitas perempuan pada zaman orde baru. Kajian ini bertujuan mengungkapkan struktur novel Saman dan menganalisis identitas sosial perempuan pada zaman orde baru di dalamnya.

\section{Feminisme Dalam Karya Sastra}

\section{a. Pengertian Karya Sastra}

Menurut kamus Bahasa Indonesia, sastra adalah kumpulan kata atau juga gaya bahasa yang dipilih untuk diekspresikan

\footnotetext{
${ }^{11}$ Surayya, R,Pendekatan Kualitatif dalam Penelitian Kesehatan. AVERROUS: Jurnal Kedokteran dan Kesehatan Malikussaleh, Vol. 1, No. 2, 2018, h. 76

${ }^{12}$ Uswatun Hasanah, Pembentukan Identitas Diri dan Gambaran Diri pada Remaja Putri Bertato di Samarinda, Vol.1, No. 2, 2013, h. 181

${ }^{13}$ Uswatun Hasanah, Pembentukan Identitas Diri dan Gambaran Diri pada Remaja Putri Bertato di Samarinda, Vol.1, No. 2, 2013, h. 180
} 
dalam kitab - kitab dan karya kesenian lalu diwujudkan dengan bahasa. Sehingga menghasilkan sebuah karya seperti karangan prosa dan puisi. ${ }^{14}$

Terdapat pendapat lain, menurut Eagleton sastra adalah karya yang berisi catatan sesuatu yang sudah ditulis dengan bentuk bahasa yang padat, dalam dan indah. Pembentukan tersebut dilakukan melalui alat bahasa. ${ }^{15}$ Di dalam sastra terdapat seni yang mengandung sisi kreativitas dan imajinasi. Imajinasi tersebut mencakup kualitas, kuantitas, dan dinamika makna. Imajinasi itu sendiri terbentuk didasarkan atas kenyataan yang merupakan sarana dalam memberikan keseimbangan dari segi rohani dan jasmani, seni sastra dapat memberikan hiburan tersendiri. ${ }^{16}$

Menurut seorang filsuf Yunani bernama Horatius, sastra memiliki fungsi dulce et utile artinya menghibur dan bermanfaat. Adapun fungsi sastra lainnya, menurut Edgar Allan Poe, sastra memiliki fungsi didactic heresy artinya menghibur dan mengajarkan sesuatu. Jika dua pendapat tersebut digabungkan, maka fungsi sastra adalah memberikan hiburan bagi pembacanya dan menambah khasanah batin. Oleh karena itu, dapat dipahami bahwa sastra akan menjadi alat/wadah untuk memberikan tanggapan personal tentang isu-isu kehidupan. ${ }^{17}$

\footnotetext{
${ }^{14}$ Desi Awar, (2002), Kamus Lengkap Bahasa Idonesia, Surabaya : Amelia, h. 446

15 Terry Eagleton, (2010), Teori Sastra: Sebuab Pengantar Komprehensif(Edisi Terjemahan Harfiah Widyawati dan Evy Setyarini), Yogyakarta:

Jalasutra, h. 4

${ }^{16}$ Nyoman Kutha Ratna, (2005), Sastra dan Cultural Studies Representasi Fiksi dan Fakta, Yogyakarta: Pustaka Pelajar, h. 541-544

${ }^{17}$ Aminuddin, (2000), Pengantar Apresiasi Karya Sastra. Bandung: Sinar Baru, h. 50
}

\section{b. Jenis-jenis Karya Sastra}

Menurut Juni Ahyar terdapat jenis sasstra yang bernama sastra imajinatif. Sastra imajinatif memiliki upaya untuk menyempurnakan realitas kehidupan. Sastra imajinatif berisi pandangan-pandangan dan makna realita kehidupan. Yang termasuk sebagai karya sastra imajinatif adalah novel. ${ }^{18}$

Kata novel diambil dari bahasa Italia yang berarti novella. Kata novella memiliki arti sebuah kisah atau cerita. Maka yang dimaksud novel yaitu sebuah karya sastra yang berbentuk prosa. Karya tersebut memiliki unsur intrinsik dan ekstrinsik. Sebuah novel umumnya berisi tentang pemaparan kehidupan manusia yang bersosialisasi dan melakukan interaksi dengan lingkungan dan sesamanya, dari cerita yang ada di novel tersebut, biasanya pengarang berusaha memberikan beberapa tanda atau kode kepada para pembaca untuk mendapatkan pesan yang tersirat seperti potret realita kehidupan. ${ }^{19}$

Menurut Fheti, novel adalah merupakan salah satu jenis karya sastra prosa yang mempunyai alur cerita yang pelik. Dapat dikatakan seperti itu dikarenakan munculnya konflik dalam novel lebih dari satu kali. Kepelikan novel ini berkaitan dengan unsur unsur dalam novel itu sendiri. Hal kompleks dan pelik ini lah yang menjadikan novel berbeda dengan cerpen. ${ }^{20}$

\footnotetext{
${ }^{18}$ Juni Ahyar, (2019), Apa itu sastra: Jenis-jenis karya sastra dan bagaimanakah cara menulis dan mengapresiasi sastra, Sleman : Deepublish, h. 15 ${ }^{19}$ Juni Ahyar, (2019), Apa itu sastra: Jenis-jenis karya sastra dan bagaimanakah cara menulis dan mengapresiasi sastra, h.148.

${ }^{20}$ Fheti Wulandari Lubis, Analisi Diskriminasi Pada Novel "Amelia" Karya Tere-Liye,Journal of Science and Social Research, Vol. 1, No. 1, 2018, h. 55
} 


\section{c. Struktur Intrinsik Novel}

Karya sastra mempunyai dua elemen besar yang merupakan sebuah hubungan yang saling berkaitan. Pertama, adalah struktur luar. Sastrawan memanfaatkan struktur luas tersebut menjadi eskpresi dengan segala daya keindahannya untuk menyampaikan struktur dalam. Kedua, adalah struktur dalam. Struktur dalam terdiri dari gagasan mengenai hakikat kehidupan dengan segala kompleks dan variasinya. Sangat wajar apabila struktur dalam dan struktur luar disampaikan secara berbeda oleh para sastrawan. Akibatnya, sastrawan dapat mengekspresikan karya sastra yang sama menjadi berbagai genre, seperti karya sastra puisi, drama, fiksi. Hal ini berkaitan dengan kreatifitas dan imajinasi sastrawan yang dipengaruhi oleh wawasan sendiri dalam menanggapi realitas dilingkungan sosialnya ${ }^{21}$

Dalam karya sastra, terdapat strukturstruktur. Sama halnya dengan karya sastra berupa novel memiliki struktur-struktur, diantaranya: abstrak dalam arti isi cerita ditemukan pada bagian awal cerita, orientasi dalam arti latar, waktu dan suasana, komplikasi dalam urutan suatu kejadian yang dihubungkan satu sama lain oleh sebab akibat terarah arti urutan kejadian yang dikaitkan sebab akibat, evaluasi dalam arti suatu konflik yang terjadi pada tahap dampak implikasi yang terarah, resolusi dalam arti bagian novel yang memunculkan solusi atas konflik, koda dalam arti bagian akhir atau penutup dalam cerita. $^{22}$

\footnotetext{
${ }^{21}$ Ali Imran Al-Ma'ruf \& Farida Nugrahani,(2017), Pengkajian Sastra: Teori dan aplikasinya, Surakarta : Dwija Amarta Press, h.6

${ }^{22}$ Juni Ahyar, (2019), Apa itu sastra: Jenis-jenis karya sastra dan bagaimanakah cara menulis dan mengapresiasi sastra, h. 150.
}

Unsur-unsur dalam Novel menurut Nurgiyantoro seperti dikutip Eli Herlina ${ }^{23}$ terdiri dari kejadian atau peristiwa, plot, tokoh atau penokohan, latar cerita, serta sudut pandang. Dengan mengkaji unsur intrinsik yang ada di dalam novel, pembaca novel tersebut dapat mendapat pesan moral baik yang terlihat maupun tersembunyi yang ingin disampaikan pengarang. ${ }^{24}$

\section{d. Kritik Sastra Feminis}

Secara etmologis kata kritik diambil dari kata "krites". Kata itu bersumber dari bahasa Yunani yang memiliki makna 'hakim'. Kata kerja dari kata tersebut adalah "krinein" (menghakimi). Kata "krinein" adalah asal mula dari kata benda "rriterion" (dasar penghakiman). ${ }^{25}$ Pengertian kata kritik menurut kamus bahasa Indonesia adalah merupakan kecaman atau tanggapan, terkadang tanggapan ini diikuti dengan pernyataan dan pertimbangan baik buruknya suatu hasil karya, pendapat, dan sebagainya. ${ }^{26}$

Yang menjadi pondasi pemikiran dalam penelitian kajian sastra dalam perspektif feminis usaha mendalami kedudukan dan peran perempuan sebagaimana termuat dalam karya sastra. Dalam meneliti karya sastra feminis tergantung pada metode

\footnotetext{
${ }^{23}$ Eli Herlina, Unsur Sosial-Budaya dalam Novel Surga Sungsang Karya Triyanto Triwikromo Sebagai Baban Pembelajaran di SMA dan Model Pembelajarannya,Bahtera Indonesia: Jurnal Penelitian Pendidikan Bahasa dan Sastra Indonesia, Vol. 1, No.2, 2017, h. 9

${ }^{24}$ Fransiska Ratna Adui, Yusuf Olang, Analisis Unsur Intrinsike dan Nilai Sosial dalam Novel Surga yang Tak Dirindukan 2 Karya Asma Nadia, Jurnal KANSASI: Pendidikan Bahasa dan Sastra Indonesia Vol.3, No.1, 2018, h. 72

${ }^{25}$ Wiyatmi. (2012). Kritik Karya Feminis Teori dan Aplikasinya dalam Sastra Indonesia, Yogyakarta: Penerbit Ombak.

${ }^{26}$ Arti Kata Kritik. KBBI Web. Diakses pada 4 Agustus 2020, dari https://kbbi.web.id/kritik.
} 
penelitian apa yang ingin dilakukan. ${ }^{27}$ Tujuan penting dan utama kritik sastra feminis dilakukan yaitu untuk mengkaji hubungan gender perempuan dan laki-laki dan keadaan ketika perempuan lebihmendominasi daripada laki-laki.

Menurut Mansour Fakih gender adalah sifat yang berasal dari konstruksi sosial maupun kultural. Sifat ini tersemat pada kaum lelaki maupun perempuan. Sifat yang menempel pada perempuan akibat konstruksi sosial yaitu perempuan itu memiliki karakter lembut, emosional, keibuan, sedangkan lakilaki itu mempunyai karakter sifat perkasa, jantan, kebapakan dan rasional. Berdasarkan budaya masyarakat dan perubahan waktu, sifat-sifat itu dapat tergantikan dan tertukarkan. Perempuan dapat memiliki sifat rasional, jantan seperti yang dimiliki lelaki. ${ }^{28}$ Kesimpulannya, konsep gender yaitu sifat yang melekat erat pada jenis kelamin perempuan dan laki-laki dan dapat berubah sesuai perkembangan kondisi budaya dan zaman. Sifat tersebut disematkan bukan karena berbedanya jenis kelamin pada keduanya, melainkan karena keinginan masyarakat dan ketentuan budaya pada masanya.

Kata kesetaraan menurut kamus bahasa Indonesa memiliki arti sejajar, seimbang. ${ }^{29}$ Sedangkan dalam bahasa Arab kata setara adalah 'adil yang artinya sama, menjadi bengkok, bertindak lalim, kejujuran dan ketulusan hati. ${ }^{30}$ Kata kesetaraan gender atau kata sejajar ini telah diperkuat dan kemudian

\footnotetext{
${ }^{27}$ Sugihastuti Suharto, (2002), Kritik Sastra Feminis, Yogyakarta: Pustaka Pelajar, h. 72.

${ }^{28}$ Mansour Fakih, (1996), Menggeser Konsep Gender dan Transformasi Sosial, Yogyakarta: Pustaka Pelajar, h. 8-9

${ }^{29}$ Depdiknas, (2001), KBBI, Jakarta: Balai Pustaka, edisi ke-3, h. 1143

${ }^{30}$ Al-Munawwir, h. 971-972.
}

disebarkan dalam GBHN tahun 1993. ${ }^{31}$ United Nation Development Program pada tahun 1995 telah menetapkan bahwa konsep kesetaraan gender adalah salah satu penanda keberhasilan pembangunan suatu negara. UNDP mengharapkan kesetaraan yang dilakukan adalah kesetaraan yang sempurna antara laki-laki dan perempuan atau bisa disebut dengan istilah 50/50 (fifty-fifty).

\section{Identitas Gender dan Sosial}

\section{a. Identitas Gender}

Gender dalam bahasa inggris memiliki arti jenis kelamin, namun dalam KBBI Indonesia sudah biasa menyebutnya 'gender'. Identitas gender adalah merupakan sebuah pengertian dan kesadaran seseorang individu mengenai gendernya sendiri. Gender berbeda dengan seksual, gender bukan dilihat dari jenis kelamin melainkan dari apa yang dia rasakan oleh orang tersebut. Istilah gender diambil dari perbedaan kehidupan sosial perempuan dan laki laki, kehidupan sosialnya bisa dari budaya itu sendiri dan kehidupan yang dia jalani. ${ }^{32}$ Agar seorang dapat mempunyai identitas gender yang sesuai dengan jenis kelaminnya, maka ia perlu diberi tahu dan ditanamkan nilai-nilai apa saja yang perlu dilakukan dan diingat tentang jenis kelaminnya serta diajak berlatih untuk berlaku sebagaimana seperti jenis kelaminnya.

\section{b. Identitas Sosial}

Identitas sosial adalah suatu pandangan diri seseorang yang lahir bermula dari adanya persepsi yang sama dan sepadan dengan anggota komunitas dalam suatu kelompok sosial dan merupakan kekhasan individu itu

\footnotetext{
${ }^{31}$ GBHN tahun 1999-2004, Surabaya: Arkola, t.t, h. 26.

${ }^{32}$ Akmaliyah, Pendidikan Kesetaraan Gender Perspektif Islam, Skripsi, 2009.
} 
sendiri. ${ }^{33}$ Identitas menurut Judith Batler adalah sesuatu atau perilaku yang sering dilakukan berulang-ulang. Identitas sendiri adalah sesuatu yang cair dan dapat berubahubah. Hal ini didukung oleh Erikson (1968) menjelaskan bahwa identitas sebagai emosi subjektif tentang diri yang selaras dan dapat berubah dari waktu ke waktu. ${ }^{34}$ Identitas dapat berubah sesuai dengan keadaan dan bergantung pada semua tindakan yang dilakukan dan dengan kelompok mana dia berbicara.

Menurut Stuart Hall dan Paul Du Gay dalam bukunya Hall Concepts of Identity bahwa identitas memiliki inti tersendiri tetapi identitas tersebut dibentuk dan dimodifikasi dengan dunia budaya luar. Identitas dibentuk dengan orang lain yang signifikan sehingga dapat memediasi subjek mengenai nilai tersebut. $^{35}$

Menurut Tajfel (1982), sebagaimana dikutip Fransisca Nurmalita Hapsari Utami ${ }^{36}$ identitas sosial yaitu suatu konsep diri seseorang, konsep ini datang dari wawasan atau pemahaman mereka tentang keterlibatan sebagai anggota dalam suatu komunitas sosial bertepatan dengan makna nilai dan perasaan dari anggota komunitas tersebut.

Pemahaman yang direkam dari seorang individu bagian kelompok atau komunitas dan dinilairelevan dengan ciri khas yang

\footnotetext{
${ }^{33}$ Teori Identitas Sosial (2019). Wikipedia. Diakses pada 4 Agustus 2020 darihttps://id.wikipedia.org/wiki/Teori_identitas_sosi al.

34 Fariz FaisalAshari, Self-Identity Waria, Thesis, 2013;Erikson, (1989), Identitas dan Siklus Hidup Manusia. Bunga Rampai.

${ }^{35}$ Stuart Hall, Paul Du Gay, (2006), Questions of cultural identity, Crane Resource Centre, h. 275.

${ }^{36}$ Fransisca Nurmalita,Hubungan Antara Identitas Sosial Dan Konformitas Pada Anggota Komunitas Virtual Kaskus Regional Depok, Proceeding PESAT (Psikologi, Ekonomi, Sastra, Arsitektur \& Teknik Sipil) Vol. 5, 2013, hlm. $94-95$.
}

dipunyai oleh dirinya merupakan identitas sosial. Ikatan emosi antar kelompok dan dirinya sendiri akan terbentuk atas keberadaan dirinya sendiri dalam suatu kelompok. Hogg \& Reid (2006), mengemukakan bahwa dasar dalam fenomena komunikatif perspektif identitas sosial adalah norma. Peran norma dalam kelompok merepresentasikan sebagai kognitif yang memiliki ketergantungan pada konteks prototipe yang menangkap sifat khas kelompok.

Dalam menghasilkan perilaku kelompok normatif, proses yang mengatur psikologis prototipe sangat berperan. Perilaku kelompok normatif ini dapat dipakai untuk mencerna persepsi. Misalnya para pemimpin yang memilki pengaruh lebih normatif dibandingkan dengan bentuk lain. Keadaan ini mengekspresikan sebagai sebuah proses pada sebuah gejala atau fenomena dan menyusun anjuran atau rekomendasi yang dirancang untuk kehidupan mendatang antara aspek identitas sosial dan kajian komunikasi. Reicher \& Levine (2006) melakukan penelitian yang hasilnya menyatakan bahwa arti penting relatif dari identitas sosial atau pribadi dapat dipengaruhi oleh manipulasi identitas dan karenanya pilihan standar untuk mengontrol perilaku.

\section{Perempuan pada Zaman Orde Baru}

Setiap masa melahirkan karya, dan salah satu karya yaitu Saman ini melahirkan karya Orde baru bisa disebut orde baru karena terdapat kekuasaan di dalamnya. Sebuah peristiwa memiliki ciri khas sosialnya sendiri termasuk pada gendernya. Hal ini ditunjukkan pada novel ini dengan menggambarkan masa pemerintahan pada tahun 1998 yang diungkapkan dalam novel ini. Hal ini ditunjukan dari seorang tokoh bernama Saman yang merupakan aktivis yang memiliki jiwa sosial, sedang melakukan 
proyek lalu tiba-tiba terjadi penyergapan sehingga Saman dimasukan ke penjara. Di dalamnya Saman disiksa, dituduh sebagai anggota komunis.

Tapi bagaimanapun yang kemudian ia terima membikin tubuhnya gemetar. Kegentaran itu tetap muncul setiap kali ia di giring keruang interrogáis, didudukan atau dibarkan berdiri, sementara ia mendiga-duga cara apa yang digunakan orang-orang kali ini, sebab matanza selalu ditutup. Kadang mereka menyundut dengan bara rokok, menjepit jarijarinya, mencambuknya meski tidak di dada, menyetrum lehernya, atau Cuma menggunakan kepalan dan tendangan ${ }^{37}$.

Orde baru sendiri merupakan julukan atau panggilan bagi masa pemerintahan presiden Soeharto. Masa orde baru ini berlangsung dari 1966 hingga $1998^{38}$. Dalam kehidupan sosial maupun masa pemerintahan orde baru itu perempuan tidak bisa lepas darinya. Dari masa ke masa yang mengalami perkembangan di dalamnya, perempuan ada di dalamnya.

Pada orde baru organisasi perempuan dan sejarah perempuan memiliki banyak lika liku. Politik orde baru memanfaatkan kekuasaannya dengan memalsukan sejarah, mendoktrinasi bahwa semua yang berbau komunis adalah tidak beradab atau jahat. Dalam upayanya mewujudkan negara tanpa komunis, seluruh organisasi yang berbau komunis, seperti misalnya organisasi perempuan Gerwani telah dihancurkan. Setelah Gerwani dibubarkan, pemerintah menunjuk Kowani (Kongres Wanita indonesia) untuk menjadi organisasi pelindung bagi semua kelompok wanita.

\footnotetext{
${ }^{37}$ Ayu Utami, (1998), Saman, Jakarta: Kepustakaan Populer Gramedia, h. 106

${ }^{38}$ Orde Baru, (2020). Wikipedia. Diakses pada 18 November 2020, dari https://id.wikipedia.org/wiki/Orde_Baru
}

Dengan ditunjuknya Kowani sebagai organisasi semua kelompok wanita bukannya membawa kabar baik dan angin segar bagi perempuan indonesia, malah sebaliknya. Kowani mendapatkan ketetapan resmi dari pemerintah dalam Panca Dharma Wanita, yaitu: 1) wanita sebagai mitra setia suami, 2) wanita sebagai pembentuk generasi penerus bangsa, 3) wanita sebagai pendidik dan pembimbing anak, 3) wanita sebagai penata rumah tangga, 4) wanita sebagai anggota masyarakat yang bermanfaat. Panca Dharma Wanita ini sangat membatasi perempuan. Saat orde baru perempuan sangat jauh dari ranah publik dan hanya berkiprah dalam keluarga. ${ }^{39}$

\section{Identitas Gender dalam Novel Saman}

Novel Saman bercerita tentang seorang mantan pastur bernama Saman dan terdapat empat orang bersahabat yang berawal sejak bangku kelas enam SD hingga mereka dewasa, yaitu Yasmin Moningka, Shakuntala, Cokorda, dan Laila. Novel Saman ini diterbitkan menjadi dwilogi Saman dan Larung. ${ }^{40}$

Dalam novel ini terdapat 4 orang pemeran utama wanita, yaitu Laila Gagarina (Laila), Yasmin Moningka (Yasmin), Cokorda Gita Magaresa (Cok), dan Shakuntala (Tala) setiap pemeran memiliki masalahnya masingmasing dan identitasnya masing-masing.

Salah satu pemeran utama di Saman yakni Laila, dia merupakan seorang Fotografer yang menyukai seorang insinyur yang sudah beristri yang bernama Sihar. Meski sudah mengetahui bahwa Sihar sudah

\footnotetext{
${ }^{39}$ Fitri Lestari, “Menilik Kembali Peran Organisasi Perempuan di Masa Orde Baru", https://www.jurnalperempuan.org/ diakses tanggal 4 Agustus 2020

$\begin{array}{lcccr} & { }^{40} \text { Saman } & \text { (Novel), (2020). } & \text { Wikipedia. } & \text { Diakses } \\ \text { pada } & 4 & \text { Agustus } & 2020, & \text { dari } \\ \text { https://id.wikipedia.org/wiki/Saman_(novel) } & \end{array}$
https://id.wikipedia.org/wiki/Saman_(novel)
} 
memiliki istri, Hasrat Laila untuk tetap menjalin hubungan dengan Sihar masih ada.

Dalam novel ini Laila mengunjungi sebuah perusahaan Texcoil untuk mengerjakan sebuah proyek bersama rekan kerja lelakinya yaitu Toni. Dalam perusahaan tersebut terlihat hanya Laila seorang perempuan di sana.

Lelaki mengidentifikasi perempuan yang bekerja di luar seperti Laila adalah sesuatu yang berbeda, dan cukup asing karena pada zaman itu perempuan memiliki identitas hanya harus bekerja di rumah dan hanya mendampingi lelaki. Hal tersebut jelas seperti yang dikemukakan oleh Mansour Fakih bahwa gender adalah suatu sifat yang yang diinterpretasi secara sosial maupun budaya yang sangat merekat erat pada kaum lelaki maupun perempuan. Perbedaan gender ini sudah biasa disampaikan kepada masyarakat baik melalui ajaran agama maupun negara. Sehingga membuat gender ini seolah-olah kodrat dari Tuhan yang tidak bisa diubah. ${ }^{41}$

Perilaku atau karakter yang erat pada perempuan adalah bahwa perempuan itu lembut, terlalu perasa, keibuan, sedangkan laki-laki itu mempunyai khas perkasa, jantan, kebapakan, logis. Sifat yang erat pada tiap gender dapat tergantikan dan ditukarkan pada laki - laki dan perempuan sebagaimana budaya tersebut berubah. Seperi contohnya di lingkungan akademik atau sekolah, seperti yang dikutip dari Jurnal Humanisma ${ }^{42}$, Di sekolah, perempuan dituntut untuk bersikap tenang dan begitu pun dengan pembelajaran yang diterima di kelas, keterampilan yang diterima identik dengan "Pekerjaan Ibu

\footnotetext{
${ }^{41}$ Mansour Fakih, (1996), Menggeser Konsep Gender dan Transformasi Sosial, h. 9-10.

${ }^{42}$ Pipit Firmanti, Penalaran Siswa Laki-laki dan Perempuan dalam Proses Pembelajaran Matematika, HUMANISMA: Journal of Gender Studies, Vol. 1 , No. 2, 2017, h. 78
}

Rumah Tangga". Berbeda halnya dengan laki-laki yang lebih mengarah pada akademik.

Perusahaan Texcoil di novel Saman adalah sebuah perusahaan perminyakan yang membutuhkan tenaga dan fisik yang kuat. Hal ini sesuai dengan identitas lelaki yang lebih kuat daripada perempuan. Budaya di Indonesia saat itu sangat membedakan mana pekerjaan untuk laki-laki dan mana untuk perempuan.

Konsep bahwa perempuan harus berada di rumah untuk mengurus urusan domestik/rumah tangga ini terjadi karena perempuan dianggap nalarnya lebih rendah daripada laki-laki. Padahal urusan domestik adalah hanya aktifitas seperti biasa, tidak ada hubungannya dengan kodrat perempuan atau laki-laki layaknya kodrat perempuan yang harus melahirkan dan kodrat laki-laki yang memilki sperma untuk pembuahan. ${ }^{43}$

Laila mulai merasa asing sebagai satusatunya perempuan di tempat ajaib ini. Tempat ini ajaib sebab cuma ada satu perempuan. Saya. ${ }^{44}$

Dalam Saman, ketidakpedulian mereka terhadap identitas bahwa perempuan harus diam di rumah, mendampingi lelaki sangat ditunjukan. Ini merupakan salah satu usaha perempuan untuk mendobrak nilai-nilai patriarki di Indonesia.

Tahap sosialisasi pertama yang dihadapi oleh anak adalah orangtua atau keluarga. Lingkungan keluarga merupakan hal yang penting dan berpengaruh kepada anak. ${ }^{45}$ Menurut Khairuddin dikutip dari Siti Aliyah dkk, peranan keluarga dalam sosialisasi ini

\footnotetext{
${ }^{43}$ Mariatul Qibtiyah,Rethinking Peran Perempuan Dalam Keluarga, KARSA: Journal of Social and Islamic Culture, Vol.23 No.1, 2015, h. 18-19 ${ }^{44}$ Ayu Utami, (1998), Saman, Jakarta: Kepustakaan Populer Gramedia, h. 8-9.

45 Siti Aliyah Fakhomah, Nurul Fatimah, Pola Sosialisasi Anak Pada Keluarga Wanita Pekerja Seksual Di Lokalisasi Gambilangu, SOLIDARITY: Jurusan Sosiologi Antropologi, Vol. 7, No. 2, 2018, h. 435
} 
memiliki fungsi penting dalam membentuk kepribadian anak. Anak akan mempelajari pola-pola tingkah laku, keyakinan dan nilainilai melalui interaksi sosial dengan keluarga. ${ }^{46}$ Salah satu pemeran utama perempuan yang dibentuk identitas oleh orangtua adalah Yasmin. Karakter Yasmin dalam buku ini sangat menunjukkan ketidakpeduliannya terhadap nilai patriarki saat itu.

Identitas Yasmin yang memilih keluar dari nilai patriarki dibentuk oleh orang tuanya. Orang tuanya membiarkan Yasmin mengikuti banyak les, dan memilih jurusan yang dia sukai hingga sekarang dia kerja di kantoran. Orang tuanya tidak berfikir tentang statement bahwa perempuan tidak perlu sekolah tinggi dikarenakan pada akhirnya akan ilmu sekolah itu tidak berguna dan akan kembali lagi ke dapur. Dalam data World Education Report (W.E.R) (1995) disebutkan bahwa, perbandingan jumlah perempuan yang melanjutkan pendidikannya di universitas adalah 48 siswa perempuan berbanding dengan 100 laki-laki. $^{47}$ Ini membuktikan bahwa perempuan yang dapat menempuh pendidikan sampai di perguruan tinggi, lebih sedikit dibandingkan dengan kaum laki-laki.

Sejak kecil, ia dibentuk orangtuanya untuk menghabiskan waktu dengan hal yang produktif. Ibunya memaksanya kursus balet, piano, berenang dan bahasa Inggris sejak kelas 2 SD, dan ia menjadi serba bisa. ${ }^{48}$

Dan Yasmin masuk Fakultas Hukum UI tampa test, sebab ia cerdas dan tekun sebingga lulus program PMDK. ${ }^{49}$

\footnotetext{
${ }^{46}$ Siti Aliyah Fakhomah, Nurul Fatimah, Pola Sosialisasi Anak Pada Keluarga Wanita Pekerja Seksual Di Lokalisasi Gambilangu, h. 435

${ }^{47}$ Akmaliyah, Pendidikan Kesetaraan Gender $\begin{array}{lll}\text { Perspektif } \quad \text { Islam, } & \text { Skripsi, }\end{array}$ http://www.dikdasmen.org/:2

${ }^{48}$ Ayu Utami, (1998), Saman, h. 149.

${ }^{49}$ Ayu Utami, (1998), Saman, h. 156
}

Dalam mendidik anak orangtua Yasmin sudah berkembang dan tidak mengikuti budaya saat itu. Selain karakter Yasmin yang dibentuk oleh orangtuanya, terdapat karakter lain yaitu Tala. Tala merupakan perempuan berdarah Jawa, sejak umur 9 tahun dia sudah kehilangan keperawanannya. Mengetahui hal tersebut, ayahnya sangat membenci Tala.

Dalam Jawa, perempuan selalu ditempatkan rendah di bawah laki-laki. Bahwa seorang perempuan harus menjadi perempuan yang ideal yang digaungkan oleh budaya, identitas seorang perempuan harus lemah lembut, penurut, tidak melawan tidak boleh melewati atau melebihi laki-laki. ${ }^{50}$ (Tanti Hermawati, 2007:21).

Suatu saat Tala ketahuan oleh ayahnya sering mendatangi pacarnya secara diam-diam di hutan, mengetahui tersebut ayahnya sangat marah dan mengatakan bahwa hanya lelaki yang harus mengejar perempuan duluan.

Malam hari ia mengikatku pada tempat tidur dan memberi aku dua pelajaran pertamaku tentang cinta. Inilah wewejangnya: Pertama. Hanya lelaki yang boleh menghampiri perempuan. Perempuan yang mengejar-ngejar lelaki pastilah sundal. Kedua. Perempuan akan memberikan tububnya pada lelaki yang pantas, dan lelaki itu akan menghidupinya dengan hartanya. Itu dinamakan perkawinan."

De Beauvoir ${ }^{52}$ juga mengatakan bahwa perempuan tidak bisa mengeluarkan sifat spontanitasnya dan cenderung pasif untuk menghindari kesan berinisiatif dalam dirinya. Karena laki-laki tidak menyukai perempuan yang terlalu berani atau itu akan menakuti mereka.

Identitas Tala di novel ini sangat bertolak belakang dengan apa yang sudah

50 Tanti Hermawati,Budaya Jawa dan Kesetaraan Gender, Jurnal Komunikasi Massa, Vol. 1, No. 1, 2007, h. 21

${ }^{51}$ Ayu Utami, (1998), Saman, h. 123.

${ }^{52}$ Simone De Beauvoir, (2019), Second Sex: Kebidupan Perempuan, Yogyakarta: Narasi-Pustaka Promothea, h. 96 
dibentuk oleh orang tuanya. Tala menunjukkan kebenciannya pada sistem patriarki. Ketika Tala ingin bepergian ke luar negeri dan mengisi beberapa dokumen yang harus mencantumkan nama ayahnya, Tala menolak.

Nama saya Shakuntala. Orang Jawa tidake punya nama keluarga."

"Anda memilikei ayah,bukan?"

"Alangkeah indahnya kalau tidak punya."

"Gunakan nama ayahmu," kata wanita di loket itu.

"Dan mengapa saya harus memakainya?"

"Formulir ini harus diisi."

Aku pun marah. "Nyonya, Anda beragama Kristen bukan? Saya tidak, tetapi saya belajar dari sekolah Katolik. Yesus tidak mempunyai ayah. Kenapa orang harus memakai nama ayah?"

Lalu aku tidak jadi memohon visa. Kenapa ayabku harus tetap memiliki sebagian dariku? Tapi haribari ini semakin banyak orang Jawa tiru-tiru Belanda. Suami istri memberi nama si bapak pada bayi mereka sambil menduga anaknya bahagia atau beruntung karena dilabirkan. Alangkah melesetnya. Alangkah naif.

Kenapa pula aku harus memakai nama ayabku? Bagaimana dengan nama ibuku? ${ }^{53}$

Suatu ketika Tala sudah dewasa dan melanjutkan kuliah. Tala melanjutkan studi di IKJ dengan pilihannya sendiri tanpa mendengarkan ayahnya. Di sini dapat ditunjukkan bahwa Tala berani mengambil keputusannya sendiri, tanpa mendengarkan ayahnya yang notabene adalah laki-laki. Menurut Akmaliyah yang dikutip dari Setiawati ${ }^{54}$, bahwa pengambilan keputusan diambil berdasarkan struktur dominan dalam keluarga tersebut. Perempuan dalam keluarga memilki struktur di bawah laki-laki, sehingga tidak banyak berkontribusi dalam keputusan. Tapi Tala mendobrak nilai Patriarki tersebut.

\footnotetext{
${ }^{53}$ Ayu Utami, (1998), Saman, h. 137

${ }^{54}$ Akmaliyah, dkk, Pengarub Perempuan Terhadap Pengambilan Keputusan Laki-lakidalam Novel Al FarisAl Jamil Karya Ali Abmad Baktsir, MUWAZAH: Jurnal Kajian Gender,Vol. 12, No. 1, 2020, h. 76
}

Setelah perang mulut dengan ayahku yang kepingin agar aku pintar, aku tetap masuk. IKJ dan terus menari. ${ }^{55}$

Bentuk lain identitas perempuan ini bukan hanya dilihat dari peran utama perempuan, penulis juga melihat dari sisi lakilaki bagaimana mereka mengidentifikasi perempuan. Dalam novel ini perempuan hanya dijadikan objek seksualitas saja. Hal ini bisa diambil kesimpulan karena Tala temannya sedang berandai tentang bagaimana Sihar menceritakan Laila dari sudut pandangnya.

Barangkali dia ber-cerita tentang seorang gadis bernama Laila Gagarina yang mengejar-ngejarnya, dengan menghapus cerita babwa lelaki itu sendiri juga suka menelepon. Dan, sepulang dari rig di laut Cina Selatan itu, dia berkata pada teman-temannya dengan gaya anteng tetapi mengandung kebusukan, "Kalian ingat, cewvek fotografer yang waktu itu ke sini?" Dan ia bercerita tentang tubub temanku Laila ketika ia menelanjanginya seperti menceritakan bonus prestasi karena menyelesaikan pekerjaan sebelum deadline, sambil mereka menatap gadis-gadis bar seolah semua bisa ditaklukan oleh uang dan otot-otot yang jantan, tanpa berpikir babwa perempuan-perempuan itu juga telah menaklukan mereka dengan bokong dan tetekbengeknya. Asu. ${ }^{56}$

Pandangan Sihar tentang Laila tersebut merupakan nilai patriarki yang sangat memarjinalkan perempuan, perempuan dianggap sebagai objek seksual bukan sebagai objek. Menurut Luce Irigaray dikutip oleh bahwa alat kelamin laki-laki merupakan bentuk dari kekuasaan atas seksualitas dan hasrat. Terdapat kuasa sosial yang dijalankan. Oleh karena itu, Sihar bisa bebas bercerita tentang tubuh Laila.

Terdapat tokoh lain di novel ini, yaitu Cok. Tidak seperti Yasmin dan Tala, identitas Cok tidak dibentuk oleh orang tuanya. Orang

\footnotetext{
${ }^{55}$ Ayu Utami, (1998), Saman, h. 156

${ }^{56}$ Ayu Utami, (1998), Saman, h. 136
} 
tua Cok tidak terlalu dijelaskan dalam novel ini. Identitas Cok lebih banyak dibentuk oleh dirinya sendiri dan dibentuk oleh lingkungan sekitarnya. Salah satunya dari sahabatnya Tala. Berkat pembentukan identitas itu, mereka memiliki kesamaan yaitu sama-sama mengadopsi kebebasan seksual.

Tokoh Cok menunjukkan bagaimana dia mematahkan aturan dan norma masyarakat tentang hubungan seksual yang hanya boleh didikte atau diatur oleh laki-laki, dan hanya menyenangkan bagi laki-laki. Selain itu, Cok mematahkan aturan bahwa perempuan tidak boleh bekerja, dia menjalankan bisnisnya sendiri.

Namun, semakin lama semakin ruwet cerita yang ia tuturkan, sebab semakin banyak nama yang dia sebut dalam surat-suratnya. Dan ia kencan dengan beberapa pria sekaligus dalam kurun waktu yang sama. Aku agak bingung membacanya. Jika terlewat satu surat saja, cerita sudah melompat ke babak baru, seperti sinetron sabun. Apakah kamu tidur dengan semua? Tidak, jawabnya. Sebagian saja. Dalam sehari kamu bisa pacaran lebih dari satu orang? Iya, tapi tidak setiap hari. Bagaimana dengan orangtuamu yang dulu membuangmu ke pelosok Republike Indonesia supaya menjadi bermoral? Mereka tak bisa marah lagi, katanya. Malah, mereka kadang terpaksa melindungi aku dari pacar-pacar yang mengamuk karena kukbianati. ${ }^{57}$

\section{Kesimpulan}

Hasil kajian ini menunjukkan bahwa : Pada novel Saman terdapat tokoh utamanya adalah Saman, sedangkan tokoh pendukungnya Yasmin, Cok, Laila dan Tala, orangtua dan Sihar. Adapun alur novel ini adalah maju mundur. Latar novel ini menggambarkan peristiwa yang terjadi pada masa orde baru. Tema pada novel ini menggambarkan perlakuan saman sebagai laki-laki kepada kaum perempuan yaitu Yasmin, Cok, Laila dan Tala yang

${ }^{57}$ Ayu Utami, (1998), Saman, h. 152 mendukungperjuangan tokoh di novel itu yang diperlakukan oleh orangtua dan Sihar. Konflik yang terjadi dalam novel itu dapat diidentifikasi sebagai analisis perjuangan feminis dalam novel ini khususnya yang terjadi pada masa orde baru.

Pada hasil analisis kritis pada novel ini menunjukkan bahwaperempuan mengalami kegelisahan karena hak-hak yang terbatas, terbukti dalam zaman orde baru terutama pada kebijakan Panca Dharma Wanita, dan hal itu memberikan pengaruh dalam pembentukan identitas sosial perempuan. Usaha yang dilakukan dalam pembentukan sosial itu adalah mencoba mematahkan perjuangan dan mentalitas perempuan untuk meraih hak-haknya dalam kehidupan sosial seperti perlakuan orangtua dan Sihar. Novel Saman karya Ayu Utami menujukkan identitas sosial perempuan keempat tokoh utama perempuan Laila, Shakuntala, Yasmin, dan Cok pada zaman orde baru. Keempat tokoh utama perempuan melakukan pendobrakan nilai-nilai dan budaya gender pada zaman itu.

Identitas yang dimiliki keempat tokoh adalah merespon budaya atau kebijakan orde baru tersebut dengan mematahkan stigma dan melawan kegelisahan tersebut. Tala yang menolak mengikuti perintah ayahnya, Cok yang menjalankan bisnisnya sendiri dan menolak didikte soal seksual oleh laki-laki, Yasmin yang sekolah sampai Perguruan Tinggi, Laila yang bekerja sebagai Fotografer. Identitas tersebut bisa terbentuk karena beberapa faktor yaitu, pembentukan dari orangtua, lingkungan dan kelompok yang memiliki emosi yang sama. 


\section{Daftar Pustaka}

\section{Buku Teks}

Al-Ma'ruf, A. I, (2017), Pengkajian Sastra: Teori dan aplikasinya. Surakarta : Dwija Amarta Press.

Aminuddin, (2000), Pengantar Apresiasi Karya Sastra. Bandung: Sinar Baru, h. 50

Anwar, D. (2002). Kamus Lengkap Bahasa Idonesia . Surabaya : Amelia.

Ashari, Fariz Faisal. (2013). Thesis, SelfIdentity Waria, Fakultas Dakwah dan Komunikasi, Jurusan Psikologi, UIN Sunan Ampel Surabaya dan Erikson, 1989, Identitas dan Siklus Hidup Manusia. Bunga Rampai. Penerjemah : Agus Cremers. Jakarta : PT. Gramedia.

De Beauvoir, S. (2019). Second Sex: Kebidupan Perempuan. Yogyakarta: NarasiPustaka Promethea, h. 96

Depdiknas, (2001), KBBI, Jakarta: Balai Pustaka, edisi ke-3, h. 1143

Eagleton, Terry, (2010), Teori Sastra: Sebuah Pengantar Komprehensif (Edisi Terjemahan Harfiah Widyawati dan Evy Setyarini), Yogyakarta: Jalasutra, h. 4

Fakih, Mansour (1996), Menggeser Konsep Gender dan Transformasi Sosial, Yogyakarta: Pustaka Pelajar, h. 8-9.

Hall, Stuart \& Du Gay, Paul. (2006). Questions of cultural identity, Crane Resource Centre, h. 275

Suharto, Sugihastuti. (2002). Kritik Sastra Feminis, Yogyakarta: Pustaka Pelajar, h. 72 .

Utami, Ayu (1998), Saman, Jakarta: Kepustakaan Populer Gramedia.

Wiyatmi. (2012). Kritik Karya Feminis Teori dan Aplikasinya dalam Sastra Indonesia, Yogyakarta: Penerbit Ombak.

Taum, Y. Y, (1997), Pengantar Teori Sastra . Bogor : Nusa Indah.

\section{Jurnal Ilmiah}

Adui, Fransiska, R. \& Olang, Yusuf, Analisis Unsur Intrinsik dan Nilai Sosial dalam Novel Surga yang Tak Dirindukan 2 Karya Asma Nadia, Jurnal KANSASI: Pendidikan Bahasa dan Sastra Indonesia Vol.3, No.1, 2018, h. 72

Akmaliyah. (2016). Al-Kalimat Al-Muta'lliqah bi Al-Musawah Al-Jenderiyah fi Al-Lugah Al-Arabiyyah wa Al-Indonesiyyah, Musâwa, Vol. 15 No. 2 Juli 2016.

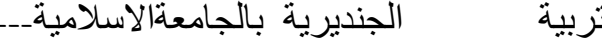
Journal of Indonesian Islam, Volume 04, Number 01, June 2010.

Pengaruh Perempuan Terbadap Pengambilan Keputusan Laki-laki dalam Novel Al Faris Al Jamil Karya Ali Ahmad Baktsir, MUWAZAH: Jurnal Kajian Gender, Vol. 12, No. 1, 2020, h. 76

AR, M. Q. H, Retbinking Peran Perempuan Dalam Keluarga. KARSA: Journal of Social and Islamic Culture, 23(1), 2015, h. 17-35.

Arsa, Dedi, SJARIKAT SIMPAN-PINJAM DAN KONGSI OESAHA: RESPON ATAS MONETERISASI KOLONLAL, HUMANISMA: Journal of Gender Vol. 1 , No. 2, 2017, h. 116

Fakhomah, Siti Aliyah \& Fatimah, Nurul, Pola Sosialisasi Anak Pada Keluarga Wanita Pekerja Seksual Di Lokalisasi Gambilangu, SOLIDARITY: Jurusan Sosiologi Antropologi, Vol. 7, No. 2, 2018, h. 435

Febrianto, Diki \& Anggraini, Purwati, Representasi Pewayangan Modern: Kajian Antropologi Sastra dalam Novel Rabvayana Aku Lala Padamu karya Sujiwo Tejo, Jentera: Jurnal Kajian Sastra, Vol. 8, No.1, Juni 2019, h.13

Firmanti, Pipit,Penalaran Siswa Laki-laki dan Perempuan dalam Proses Pembelajaran Matematika,HUMANISMA: Journal 
of Gender Studies, Vol. 1 , No. 2, 2017, h. 78

Hasanah, Uswatun Pembentukan Identitas Diri dan Gambaran Diri pada Remaja Putri Bertato di Samarinda, Vol.1, No. 2, 2013, h. 181

Herlina, Eli, Unsur Sosial-Budaya dalam Novel Surga Sungsang Karya Triyanto Triwikromo Sebagai Bahan Pembelajaran di SMA dan Model Pembelajarannya, Babtera Indonesia: Jurnal Penelitian Pendidikan Bahasa dan Sastra Indonesia, Vol. 1, No.2, 2017, h. 9

Hermawati, Tanti, Budaya Jawa dan Kesetaraan Gender, Jurnal Komunikasi Massa, Vol. 1, No. 1, 2007, h. 21

Lubis, Fheti, W, Analisi Diskriminasi Pada Novel "Amelia" Karya Tere-Liye, Journal of Science and Social Research, Vol. 1, No. 1, 2018, h. 55

Lestari, Fitri "Menilik Kembali Peran Organisasi Perempuan di Masa Orde Baru", https://www.jurnalperempuan.org/ diakses tanggal 4Agustus 2020

Mutiah, R., SISTEM PATRIARKI DAN KEKERASAN ATAS PEREMPUAN. KOMUNITAS, Vol. 10, No. 1, 2019, h. 58-74.

Nadia, Zunly, Peran dan Aktivitas Perempuan Era Muhammad SAW (Studi Atas Hadis-Hadis Riwayat Sababat Perempuan), Humanisma: Journal of Gender Studies, Vol.04, No.01, 2020, h. 17

Nurmalita, Fransisca, Hubungan Antara Identitas Sosial Dan Konformitas Pada Anggota Komunitas Virtual Kaskus Regional Depok, Proceeding PESAT (Psikologi, Ekonomi, Sastra, Arsitektur \& Teknik Sipil) Vol. 5, 2013, hlm. 94 - 95.

Qibtiyah, Mariatul, Retbinking Peran Perempuan Dalam Keluarga, KARSA: Journal of Social and Islamic Culture, Vol.23 No.1, 2015, h. 18-19
Patriana, Rina, Representasi Seksualitas Dalam Novel Saman Karya Ayu Utami, Humaniora Vol.3 No.2, 2012, h. 370

R, Surayya, Pendekatan Kualitatif dalam Penelitian Kesehatan. AVERROUS: Jurnal Kedokteran dan Kesehatan Malikussaleh, Vol. 1, No. 2, 2018, h. 76

Wiranty, Wiendi, Tindak Tutur dalam Wacana Novel Laskar Pelangi Karya Andrea Hirata (Sebuab Tinjanan Pragmatik), Jurnal Pendidikan Bahasa, Vol. 4, No. 2, 2015, h. 295

\section{Makalah Ilmiah dan Artikel}

Ahyar, J, (2019), Apa itu sastra: Jenis-jenis karya sastra dan bagaimanakah cara menulis dan mengapresiasi sastra. Sleman : Deepublish .

Akmaliyah. (2009). Disertasi, Pendidikan Kesetaraan Gender Perspektif Islam Studi Kasus UIN Sunan Gunung Djati Bandung, Program Pascasarjana UIN Sunan Gunung Djati Bandung.

GBHN tahun 1999-2004, Surabaya: Arkola, t.t, h. 26.

Hapriyonita, Sarastika E. (2018). Skripsi, Teknik Dan Metode Penerjemahan Novel Naib Trrail Oleh Kamran As'ad Irsyady (Kajian Terjemah), Jurusan Bahasa dan Sastra Arab, Fakultas Adab dan Humaniora, UIN Sunan Gunung Djati Bandung.

Komnas Perempuan. (2019). Korban Bersuara, Data Bicara Sabkan RUU Penghapusan Kekerasan Seksual Sebagai Wujud Komitmen Negara Catatan Kekerasan Terhadap Perempuan Tabun 2018.

\section{Referensi Online}

KBBI Web, “Arti Kata Kritik", https://kbbi.web.id/kritik, diakses pada 4 Agustus 2020. 
Wikipedia, "Ayu Utami”, https://id.wikipedia.org/wiki/Ayu_U tami diakses pada 3 Agustus 2020

Wikipedia, "Saman (Novel)", https://id.wikipedia.org/wiki/Saman _(novel) diakses pada 4 Agustus 2020

Wikipedia, "Teori Identitas Sosial" https://id.wikipedia.org/wiki/Teori_i dentitas_sosial. diakses pada 4 Agustus 2020.

Wikipedia, "Orde Baru" https://id.wikipedia.org/wiki/Orde_ Barudiakses pada 18 November 2020. 